\title{
Biogeographical affinities and species richness of copronecrophagous beetles (Scarabaeoidea) in the southeastern Mexican High Plateau
}

\section{Afinidades biogeográficas y riqueza de especies de escarabajos copronecrófagos (Scarabaeoidea) en el sureste del altiplano mexicano}

\author{
Alfonsina Arriaga ${ }^{1}$, Gonzalo Halffter ${ }^{1 \otimes}$ and Claudia Moreno $^{2}$ \\ ${ }^{1}$ Instituto de Ecología, A.C. Carretera Antigua a Coatepec No. 351, El Haya, 91070 Xalapa, Veracruz, México. \\ ${ }^{2}$ Centro de Investigaciones Biológicas, Universidad Autónoma del Estado de Hidalgo. Ciudad Universitaria, Km. 4.5 Carretera Pachuca-Tulancingo, \\ 42184, Pachuca, Hidalgo, México. \\ \gonzalo.halffter@inecol.edu.mx
}

\begin{abstract}
In this study we establish the biogeographical affinities of the Scarabaeoidea dung beetle fauna in the dry southeast of the Mexican Plateau and analyze species diversity and how it changes with site, soil and vegetation type. Beetles were systematically captured in 6 windows in the region between Perote, Veracruz and El Seco, Puebla. A total of 9 species and 960 beetles belonging to Scarabaeinae, Aphodiinae and Trogidae were captured. Canthon humectus humectus and Phanaeus quadridens were found in greater abundance in cattle pastures. Trox plicatus is the only species captured in the badlands. The beetle fauna of this landscape is poor owing to a combination of circumstances, mainly the soil, recent volcanic activity and limited food availability. The results obtained are compared with those of 2 other dry landscapes in central Mexico (Metztitlán and Tehuacán). Our landscape shares $50 \%$ of its species with Metztitlán and $37.5 \%$ with Tehuacán. The species shared between all 3 landscapes are Canthon (B.) puncticollis, Onthophagus lecontei and Labarrus pseudolividus. The fauna was characteristic of the southern Mexican Plateau, but poorer in both the number of species and individuals; some species_ expected from a biogeographic perspective — were missing.
\end{abstract}

Key words: copronecrophagous beetles, Mexican High Plateau, Scarabaeinae, Aphodiinae, geographic distribution.

Resumen. Establecemos las afinidades biogeográficas de los Scarabaeoidea copronecrófagos del sureste seco del altiplano mexicano, así como la diversidad de especies y sus cambios en diferentes sitios, tipos de vegetación y suelos. Se recolectó en 6 diferentes ventanas entre Perote, Veracruz y El Seco, Puebla, obteniéndose un total de 9 especies y 960 individuos de Scarabaeinae, Aphodiinae y Trogidae. Canthon humectus humectus y Phanaeus quadridens fueron más abundantes en las áreas de pastoreo de ganado. Trox plicatus fue la única especie capturada en la zona de malpaís. En conjunto, la fauna de este paisaje es pobre debido a una combinación de circunstancias, principalmente la naturaleza del suelo, el vulcanismo reciente y la baja disponibilidad de alimento. Se comparan los resultados obtenidos, con los relativos a otros 2 paisajes áridos del centro de México (Metztitlán y Tehuacán). Nuestro paisaje comparte el $50 \%$ de las especies con Metztitlán y el 37.5\% con Tehuacán. Las especies compartidas entre los 3 son Canthon (B.) puncticollis, Onthophagus lecontei y Labarrus pseudolividus. En síntesis, se encontró una fauna característica del altiplano mexicano sur, pero pobre en cuanto al número de especies e individuos (faltan especies cuya presencia era esperada desde un enfoque biogeográfico).

Palabras clave: escarabajos copronecrófagos, altiplano mexicano, Scarabaeinae, Aphodiinae, distribución geográfica.

\section{Introduction}

The 2 large biogeographical regions of the Americas come into contact in Mexico. For present-day birds and mammals the area of contact that separates the 2 regions is fairly well defined, and was identified from the first studies of historic biogeography (Sclater, 1858; Wallace, 1876). For groups dominated by lines with much older

Recibido: 24 mayo 2011; 26 octubre 2011 distributions, this border becomes a broad area of overlap. This has been stated by Halffter $(1964,1976)$ on studying insect distribution and by Rzedowski (1972, 1973) for flowering plants. For this area of contact-overlap between the Nearctic and Neotropical regions, Halffter (1987) coined the term Mexican Transition Zone (MTZ) and Rzedowski (1991) referred to it as Megamexico.

Located in the Mexican Transition Zone, the Mexican Plateau, has a mean altitude of $2000 \mathrm{~m}$ a.s.1., and reaches $2400 \mathrm{~m}$ a.s.l. in its southern extreme resulting in a temperate climate with a dry winter and a warm, 
moderately rainy summer. The Plateau is located in the central and northern part of Mexico and covers one quarter of the country. It is bordered by a large horseshoeshaped chain of mountains formed by the Sierra Madre Occidental Mountain Range, the Trans-Mexican Volcanic Belt (its southernmost part) and the Sierra Madre Oriental Mountain Range.

In Mexico establishing the general tendencies of insect distribution (or those of any other biotic group of equivalent biogeographic antiquity) is a complex task. In the MTZ not only do elements of different biogeographical origins overlap, but these elements also made their way to the MTZ during different geological periods and under different paleogeographic scenarios. Briefly, for the 2 large trunks of origin (northern and southern), we can identify genera or species lines whose penetration into the MTZ is ancient (up to the Miocene) as well as genera of more recent penetration (from the Pliocene onwards).

As an instrument for the analysis of this complex scenario, Halffter (1962, 1964, 1976, 1987) proposed 5 distribution patterns that have been widely applied by different authors (as examples Zunino and Zullini, 1995; Llorente-Bousquets, 1996; Marshall and Liebherr, 2000; Morrone and Marquez, 2001; Reyes-Castillo, 2003). These distribution patterns are based on the origin, the phylogeny of the biota and the climate and geological history of the region. Each pattern brings together the essential characteristics of the distribution of the group of organisms that originated in or arrived at a given area during a geological period and which has been subjected to similar macroecological pressures over long periods of time (Halffter, 1987).

The origin of the scarabeids beetles characteristic of the Mexican Plateau is complex. There are elements that are clearly of very old South American origin that evolved on the Plateau after its elevation. In addition to these insects, there are elements from the north - also of ancient penetration. Nearctic elements of modern penetration are limited to the mountain ranges. Thus the Plateau has acted as an important center of speciation and its insect fauna has a good number of endemic elements, particularly at the species level (Halffter, 1987).

The fauna of the southern Mexican Plateau is relatively poor in comparison with the tropical regions of the country. It is also a region that has received little study. Some of the recent research in the central and eastern part of the southern Mexican Plateau includes 1 by Halffter et al. (2008) on the copronecrophagous Scarabaeoidea fauna (Geotrupinae and Scarabaeinae) of the Barranca de Metztitlán (a dry region of the Plateau) and that of Halffter et al. (2010) in which they compared the dung beetle fauna (Scarabaeinae and Aphodiini) of 2 arid zones in central
Mexico: the Barranca de Metztitlán Canyon and the region of Zapotitlán Salinas (Tehuacán).

We used the copronecrophagous Scarabaeoidea of the Scarabaeinae and Aphodiinae subfamilies and the Trogidae family. Our objectives were to: a) Describe the distribution of the assemblage of copronecrophagous beetles of the dry southeastern region of the Mexican Plateau in ecological and biogeographical terms, b) Describe the species richness and composition for different sites, vegetation types and soil types, c) Compare and analyze the similarities and differences among the copronecrophagous beetles of this arid zone with respect to other, similar zones in central Mexico, d) Discuss the factors that have affected this assemblage of beetles in particular, in comparison with those of other arid regions in central Mexico.

\section{Materials and methods}

Study area. The study region lies between the Valley of Perote in the state of Veracruz and the municipality of El Seco in the State of Puebla. It includes the base of the Trans-Mexican Volcanic Belt on the southeastern part of the Mexican Plateau. The town of San Salvador El Seco is located in central eastern Puebla at $19^{\circ} 04^{\prime}-19^{\circ} 15^{\prime}$ $\mathrm{N}, 97^{\circ} 32^{\prime}-97^{\circ} 42^{\prime} \mathrm{W}$, at an altitude of $2400 \mathrm{~m}$ a.s.l. The predominant climates are: temperate subhumid with rains during summer and a temperate semidry season with scarce rainfall during winter.

The town of Perote is located at $19^{\circ} 34^{\prime} \mathrm{N}, 97^{\circ} 15^{\prime}$ $\mathrm{W}, 2400 \mathrm{~m}$ a.s.l. Its climate is dry and fairly cool with a mean temperature of $12{ }^{\circ} \mathrm{C}$ and an average of $493.6 \mathrm{~mm}$ of rainfall yearly. There are areas called badlands throughout the region, and these are comprised of basalt flows that surfaced and cover a vast expanse around Frijol Colorado (Veracruz) and Guadalupe Sarabia (Puebla).

The Perote Valley has rocky, alluvial soils. Alluvial soils have a low water retention capacity and erode easily. Because of this and the high proportion of rocks of different sizes in them the least productive soils for agriculture are found in this region (Portilla, 1980). During the rainy season (July, August, September and October) ephemeral streams flow down the hillsides and form an endorheic basin in the lowest parts of the valley where the runoff collects salts that are deposited in the silty-clay soil.

The following types of vegetation are found in the study region: a), Distichlis spicata halophile pasture; b), spiny scrub and Nolina parviflora-Yucca periculosa scrub (sensu Miranda and Hernández, 1963; xerophile scrub according to Rzedowski, 1978), which grows on rocky soils; c), Sabino forest (Juniperus deppeana), or juniper and Mexican piñon pine forest (Pinus cembroides - Juniperus flaccida) (sensu Miranda and Hernández, 
1963; coniferous forest according to Rzedowski, 1978), Phoradendron minutifolium - a parasite of Juniperusand Spanish moss (Tillandsia usneoides) occur as epiphytes (Cházaro, 1992). Characteristic associations of Nolina-Agave, Hechtia-Agave and Juniperus are found at the base of calcareous hills, in addition to associations of Juniperus flaccida-Pinus cembroides and Cupressus benthamii in the region of Frijol Colorado (Cházaro, 1992).

People have intensively used the entire region for a very long time. Much of the land is used for agriculture (corn, barley, fruit trees, etc.) and raising livestock is widespread. There are also many fields that were ploughed at one time and later abandoned. Mostly goats and sheep are raised, and to a lesser extent cattle. The animals are pastured on the croplands before sowing, after which they are herded to the hillsides and plains not used for crops. The badlands are much less affected by human activities because they are unsuitable for pasturing animals or sowing crops.

Sampling design, description and location of the sampling windows. Six sites were selected that differ with respect to soil and vegetation type between Perote and El Seco (Fig. 1). The sites were located between 2300 and $2,500 \mathrm{~m}$ a.s.l. and were separated by at least $5 \mathrm{~km}$. All were located on the same landscape and share the same biogeographic history. Because of this any differences in species richness and abundance are expected to be a function of vegetation types, dung availability or the soil characteristics at each site.

At each site a sampling quadrat or "window" of 500 x $500 \mathrm{~m}$ was set up. Four of the 6 windows include a heterogeneous mosaic of different types of vegetation (none of which are crops) and 2 are located in areas used

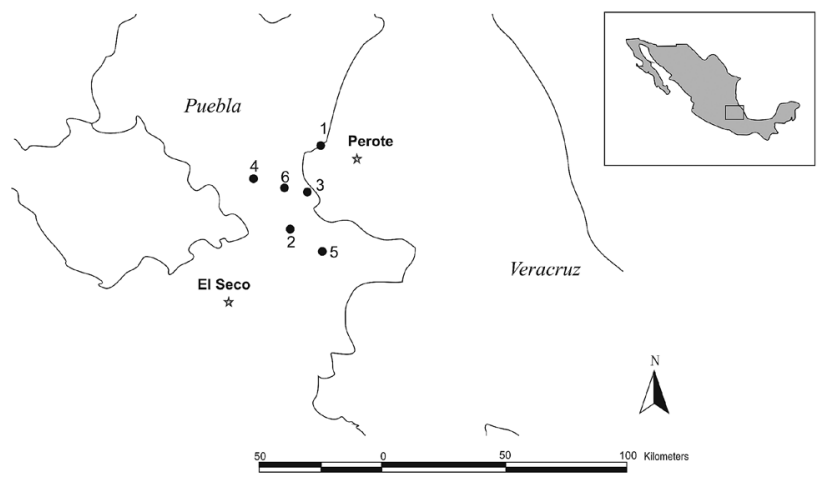

Figure 1. Location of the study region in the southern part of the Mexican High Plateau in the states of Puebla and Veracruz. Dots indicate the sampling sites (windows) used in this study and the stars show the location of the towns of El Seco and Perote. for pasturing animals and have a high degree of human activity.

The types of vegetation originally identified were grouped according to plant cover as follows: the pinesabino forest together with the juniper forest were put together as forest; Nolina and Yucca scrub were put together with xerophile scrub as low scrub; halophile pasture and livestock herding routes were grouped together as anthropic vegetation, given that both have been modified by humans. Soil in the region is classified according to texture and rockiness into 4 types: loam, loamy soil with a high proportion of rocks, sandy and rocky (badlands).

Data bases and maps from Conabio were used to characterize the windows and obtain information regarding soil type, precipitation, mean annual temperature, climate, land use and vegetation type for each window (Table 1, Fig. 1).

Beetles were caught using pitfall traps baited with decomposing squid and different types of excrement. Traps were separated by at least $50 \mathrm{~m}$. Twenty-four traps were set in each window: 8 with human excrement, 8 with sheep $(70 \%)$ and horse (30\%) dung, and 8 permanent NTP-80 carrion traps (Morón and Terrón, 1984). Traps were set with alternating bait along the entire window. Each trap was left for $48 \mathrm{~h}$ and sampling was repeated 6 times per window $(24 \times 6=144$ traps per window). Sampling was carried out during the rainy season (July, August and September) in 2009 and 2010, and beetles were also collected directly from the surface at each sampling window and in the surroundings.

Beetles collected were identified to species. Francisco Cabrero (Madrid University, Spain) identified the Aphodiinae, and Mario Zunino (Urbino University, Italy) identified the Onthophagus; remaining species were identified by the authors.

Analysis based on sampling windows. To analyze a landscape, most studies compare different types of patches (e.g. vegetation types, habitats, types of land use, ecoregions, altitudes and other descriptive categories). One alternative that might be more comprehensive is to spatially sample the entire landscape randomly. Different studies have used samples with more than 1 type of patch in a heterogeneous landscape (Lindenmayer et al., 2003; Arroyo-Rodríguez et al., 2009; Numa et al., 2009). Thus, for the present study a similar methodology was used, and each of the sampling quadrats is called a window.

The windows method is based on using quadrants that have more than 1 type of vegetation, and even though the windows are heterogeneous they can be used as representative samples of the landscape. The method also allows one to see the effect of different proportions of vegetation types 
Table 1. Characteristics of the 6 sampling windows in the region around Perote in the state of Veracruz and El Seco in the state of Puebla. Information marked with an asterisk was obtained from Conabio's data bases. The rest was obtained during sampling and each window was georeferenced with a GPS

\begin{tabular}{|c|c|c|c|c|c|c|}
\hline & \multicolumn{6}{|c|}{ Window } \\
\hline & 1 & 2 & 3 & 4 & 5 & 6 \\
\hline $\begin{array}{l}\text { Vegetation at the } \\
\text { window }\end{array}$ & yucca/scrub & pasture/juniper & $\begin{array}{l}\text { yucca, juniper/ } \\
\text { cacti and agaves }\end{array}$ & $\begin{array}{l}\text { pine/pasture/ } \\
\text { yucca, juniper }\end{array}$ & pasture/scrub & pasture \\
\hline Longitude & $97^{\circ} 22^{\prime} 04^{\prime \prime} \mathrm{W}$ & $97^{\circ} 28^{\prime} 31^{\prime \prime} \mathrm{W}$ & $97^{\circ} 23^{\prime} 13^{\prime \prime} \mathrm{W}$ & $97^{\circ} 31^{\prime} 14^{\prime \prime} \mathrm{W}$ & $97^{\circ} 21^{\prime} 17^{\prime \prime} \mathrm{W}$ & $97^{\circ} 26^{\prime} 18^{\prime \prime} \mathrm{W}$ \\
\hline Latitude & $19^{\circ} 36^{\prime} 23^{\prime \prime} \mathrm{N}$ & $19^{\circ} 20^{\prime} 18^{\prime \prime} \mathrm{N}$ & $19^{\circ} 27^{\prime} 50^{\prime \prime} \mathrm{N}$ & $19^{\circ} 30^{\prime} 22^{\prime \prime} \mathrm{N}$ & $19^{\circ} 17^{\prime} 35^{\prime \prime} \mathrm{N}$ & $19^{\circ} 28^{\prime} 27^{\prime \prime} \mathrm{N}$ \\
\hline Soil type* & eutric regosol & $\begin{array}{l}\text { calcaric rego- } \\
\text { sol and calcaric } \\
\text { phaeozems }\end{array}$ & $\begin{array}{l}\text { takiric solon- } \\
\text { chak and eutric } \\
\text { regosol }\end{array}$ & $\begin{array}{l}\text { lithosol, calcaric } \\
\text { regosol and eutric } \\
\text { regosol }\end{array}$ & $\begin{array}{l}\text { eutric fluvisol } \\
\text { and eutric } \\
\text { regosol }\end{array}$ & eutric fluvisol \\
\hline Climate* & $\begin{array}{l}\text { BS } 1 \mathrm{kw} \text { semia- } \\
\text { rid temperate }\end{array}$ & $\begin{array}{l}\mathrm{C}(\text { wo }) \text { subhu- } \\
\text { mid temperate }\end{array}$ & $\begin{array}{l}\text { BS okw } \\
\text { arid temperate }\end{array}$ & $\begin{array}{l}\text { Bs } 1 \mathrm{kw} \text { semiarid } \\
\text { temperate }\end{array}$ & $\begin{array}{l}\text { Bs } 1 \mathrm{kw} \text { semia- } \\
\text { rid temperate }\end{array}$ & $\begin{array}{l}\text { BS okw } \\
\text { arid temperate }\end{array}$ \\
\hline $\begin{array}{l}\text { Annual tempe- } \\
\text { rature range }(\mathrm{T} \\
\left.{ }^{\circ} \mathrm{C}\right) *\end{array}$ & $\begin{array}{l}12^{\circ} \mathrm{C}-18^{\circ} \mathrm{C} \\
\min : 0-2^{\circ} \mathrm{C}, \\
\max : 22-4^{\circ} \mathrm{C}\end{array}$ & $\begin{array}{l}12^{\circ} \mathrm{C}-18^{\circ} \mathrm{C} \\
\min :-2-0^{\circ} \mathrm{C}, \\
\max : 22-24^{\circ} \mathrm{C}\end{array}$ & $\begin{array}{l}12^{\circ} \mathrm{C}-18^{\circ} \mathrm{C} \\
\min :-2-0^{\circ} \mathrm{C}, \\
\max : 24-26^{\circ} \mathrm{C}\end{array}$ & $\begin{array}{l}12^{\circ} \mathrm{C}-18^{\circ} \mathrm{C} \\
\min : 0-2^{\circ} \mathrm{C} \text {, max: } \\
26-8^{\circ} \mathrm{C}\end{array}$ & $\begin{array}{l}12^{\circ} \mathrm{C}-18^{\circ} \mathrm{C} \\
\min : 0-2^{\circ} \mathrm{C}, \\
\max : 24-6^{\circ} \mathrm{C}\end{array}$ & $\begin{array}{l}12^{\circ} \mathrm{C}-18^{\circ} \mathrm{C} \\
\min : 0-2^{\circ} \mathrm{C}, \\
\max : 24-6^{\circ} \mathrm{C}\end{array}$ \\
\hline Precipitation * & $600-800 \mathrm{~mm}$ & $400-600 \mathrm{~mm}$ & $400-600 \mathrm{~mm}$ & $600-800 \mathrm{~mm}$ & $400-600 \mathrm{~mm}$ & $600-800 \mathrm{~mm}$ \\
\hline $\begin{array}{l}\text { Vegetation and } \\
\text { land use * }\end{array}$ & $\begin{array}{l}\text { rosette scrub } \\
\text { surrounded by } \\
\text { agricultural } \\
\text { fields }\end{array}$ & $\begin{array}{l}\text { pine forest } \\
\text { surrounded by } \\
\text { agricultural } \\
\text { fields }\end{array}$ & $\begin{array}{l}\text { halophylic and } \\
\text { gypsophilic } \\
\text { vegetation } \\
\text { surrounded by } \\
\text { agricultural } \\
\text { fields and rosette } \\
\text { scrub }\end{array}$ & $\begin{array}{l}\text { pine forest surroun- } \\
\text { ded by agricultural } \\
\text { fields and rosette } \\
\text { scrub }\end{array}$ & $\begin{array}{l}\text { halophylic } \\
\text { vegetation } \\
\text { surrounded by } \\
\text { agricultural } \\
\text { fields }\end{array}$ & $\begin{array}{l}\text { halophylic and } \\
\text { gypsophilic } \\
\text { vegetation with } \\
\text { no visible veg- } \\
\text { etation in the } \\
\text { surroundings }\end{array}$ \\
\hline Rockiness* & $\begin{array}{l}\text { high, few sites } \\
\text { with soil }\end{array}$ & $\begin{array}{l}\text { low, site have } \\
\text { enough soil } \\
\text { for the beetles } \\
\text { to dig }\end{array}$ & $\begin{array}{l}\text { moderate, raised } \\
\text { areas of soil } \\
\text { available for the } \\
\text { beetles to dig }\end{array}$ & $\begin{array}{l}\text { low, ample soil } \\
\text { cover }\end{array}$ & $\begin{array}{l}\text { low, areas of } \\
\text { soil available } \\
\text { for the beetles } \\
\text { to dig }\end{array}$ & $\begin{array}{l}\text { low, areas of } \\
\text { soil available } \\
\text { for the beetles } \\
\text { to dig }\end{array}$ \\
\hline component & volcanic & calcareous & $\begin{array}{l}\text { calcareous and } \\
\text { volcanic }\end{array}$ & calcareous & calcareous & $\begin{array}{l}\text { calcareous and } \\
\text { volcanic }\end{array}$ \\
\hline
\end{tabular}

or of any other component of the landscape. Additionally, we can use conventional methods for vegetation type, soil type, etc. if we group together the points with the same type of characteristics (vegetation, soil type, etc.) regardless of which window they are found in.

Regarding the percentages of vegetation present at each window, window 1 has more than $70 \%$ low scrub and the rest is forest with anthropic vegetation, window 2 has more than $60 \%$ anthropic vegetation and the rest is forest, mainly Juniperus deppeana, window 3 has approximately $60 \%$ low scrub, less than $10 \%$ is anthropic vegetation and the rest is forest, window 4 has more than $50 \%$ forest and the other $50 \%$ is low scrub, window 5 has more than $80 \%$ anthropic vegetation and the rest is low scrub, window 6 is completely anthropic vegetation as it is located on a plain used for pasturing livestock.

Data analysis. To evaluate inventory completeness and sampling effort, observed and expected species richness were compared (Waide et al., 1999; Moreno and Halffter, 2000). Species accumulation curves were used and for expected richness Chao1 and Chao2 estimators were used, both were calculated using the EstimateS program. ver. 7.5.2 (Colwell, 2005). Inventory completeness for each window was measured as the percentage that the observed species represented of the total expected number of species.

A Detrended Correspondence Analysis (DCA) was done using the Past software (Hammer et al., 2009), to observe graphically the differences in species composition at each window and on different types of soil. DCA is an indirect ordination method that allows samples to be ordered according to species distribution and abundance (Hill and Gauch, 1980). DCA was used, rather than any other type of analysis, because it corrects for the "arch effect" that occurs in Correspondence Analysis (Legendre 2000; Gauch, 1982; Hill and Gauch, 
1980). Following the DCA the windows were compared and the vegetation types were compared. Additionally, the structure of the windows was evaluated to reveal how species composition changes between windows.

Complementarity was measured between windows and between vegetation types using the index described by Colwell and Coddington (1994). This index is expressed as a percentage and is $0 \%$ when the species composition of 2 windows is identical, and $100 \%$ when the species composition at the 2 windows is completely different. Thus, it is a way of measuring beta diversity (Magurran, 2004).

The biogeographic affinity of each species was searched in the literature (Vaurie, 1955; Halffter and Martínez, 1977; Zunino and Halffter, 1988; Lobo, 1996; Dellacasa et al., 2002; Halffter and Halffter, 2003; Cabrero-Sañudo et al., 2010). The community of copronecrophagous beetles from this region was compared with that of the Barranca de Metztitlán in the state of Hidalgo (a unique arid and semiarid region in the south of the Mexican High Plateau where the copronecrophagous Scarabaeoidea fauna has been well collected (Verdú et al., 2007; Halffter et al., 2008; Halffter et al., 2010) and with that of TehuacánCuicatlán, with respect to similarities and differences in species composition.

\section{Results}

A total of 9 species were caught over the entire landscape: 7 had fallen into the traps and 2 were collected directly from the surroundings (Table 2). Six of the species belong to the Scarabaeinae subfamily, 2 to Aphodiinae and 1 to the Trogidae family.

Within the Scarabaeinae, there are no strict necrophages. A total of 960 beetles were captured, 883 of them in carrion traps and dung traps, and 77 were collected directly in the areas surrounding the sampling windows.

Where cattle is pastured Canthon humectus humectus and Phanaeus quadridens were found in greater abundance, as the Aphodiinae species that were directly caught outside of the quadrats set up at each window.

The species accumulation curve (Fig. 2) reveals that, although the asymptote was not reached, the number of species expected according to the Chao1 and Chao2 estimators ( 7 species) was, indicating that we caught $100 \%$ of the species expected with this sampling method. The doubletons disappear at the end of the curve and leave only 1 singleton: Onthophagus mexicanus.

The most effective trap was the dung traps with human excrement, which had the highest abundance with 7 species caught in these traps. The carrion traps attracted

Table 2. Species captured in the region around Perote in the state of Veracruz and El Seco in the state of Puebla. The abundance of each species is given for each window

\begin{tabular}{|c|c|c|c|c|c|c|c|c|}
\hline & & & & indow & & & & \\
\hline Species & 1 & 2 & 3 & 4 & 5 & 6 & Direct Collection & Total \\
\hline $\begin{array}{l}\text { Canthon (Boreocanthon) puncticollis } \\
\text { LeConte, } 1866\end{array}$ & & & 40 & & 10 & & & 50 \\
\hline $\begin{array}{l}\text { Canthon humectus humectus } \\
\text { Say, } 1832\end{array}$ & & & & & 1 & 20 & 6 & 27 \\
\hline $\begin{array}{l}\text { Onthophagus chevrolati retusus } \\
\text { Harold, } 1869\end{array}$ & & & & 369 & 4 & & 9 & 382 \\
\hline $\begin{array}{l}\text { Onthophagus lecontei } \\
\text { Harold, } 1871\end{array}$ & & 7 & 37 & 107 & 69 & 14 & 5 & 239 \\
\hline $\begin{array}{l}\text { Onthophagus mexicanus } \\
\text { Bates, } 1887\end{array}$ & & & & 1 & & & & 1 \\
\hline $\begin{array}{l}\text { Phanaeus quadridens } \\
\text { Say, } 1835\end{array}$ & & & 1 & & 1 & 15 & 32 & 49 \\
\hline $\begin{array}{l}\text { Trox plicatus } \\
\text { Robinson, } 1940\end{array}$ & 24 & 1 & 49 & 113 & & & & 187 \\
\hline $\begin{array}{l}\text { Labarrus pseudolividus } \\
\text { Balthasar, } 1941\end{array}$ & & & & & & & 10 & 10 \\
\hline \multirow{2}{*}{$\begin{array}{l}\text { Pseudagolius coloradensis } \\
\text { Horn, } 1870\end{array}$} & & & & & & & 15 & 15 \\
\hline & 24 & 8 & 127 & 590 & 85 & 49 & 77 & 960 \\
\hline
\end{tabular}




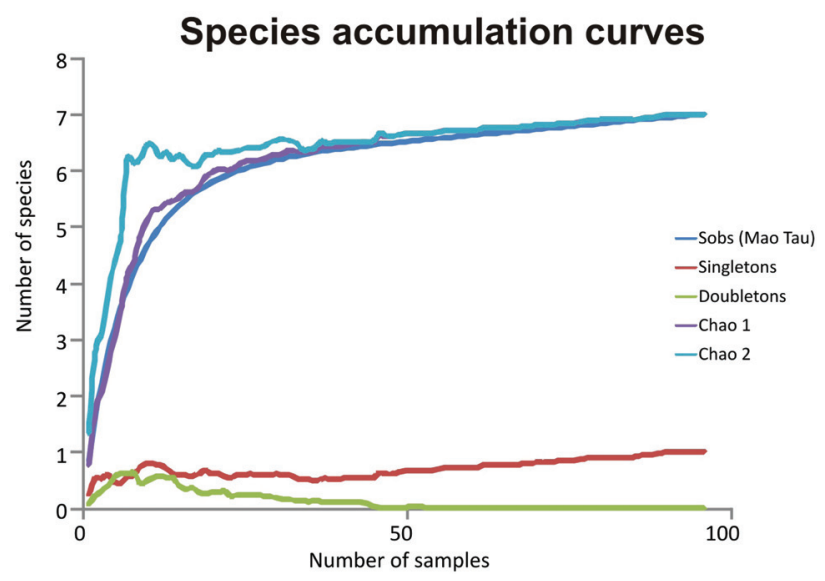

Figure 2. Species accumulation curve indicating the number of species captured ( $\mathrm{Y}$ axis) with respect to the number of samples (X axis), randomizing the data 100 times using the EstimateS program. The Chao 1 and Chao 2 richness estimators, along with the number of singletons and doubletons were also plotted to determine sampling efficiency.

a high number of beetles (398), but only captured Trox plicatus and Onthophagus chevrolati retusus. The latter species was also caught in great numbers in the dung traps with human excrement suggesting that it is very abundant and has broad feeding preferences. Even though dung traps baited with sheep and horse dung were effective in the Barranca de Metztitlán (Verdú et al., 2007), in this landscape they did not attract any species at all.

Window 5 had the highest number of species $(n=5)$, followed by windows 3 and 4 with 4 species each. Window 4 had the greatest abundance of individuals, much higher than that recorded for the other windows $(n=590)$. There were significant differences in the richness of the windows $(\mathrm{H}=24.51, p \leq 0.001)$, with window 4 significantly different from all the others owing to its elevated abundance (Mann-Whitney paired comparison with the Bonferroni correction). There was no significant difference between windows 3,5 and 6 , for all of which richness was high and abundance similar.

On analyzing the structure of the community, Trox plicatus can clearly be observed to be the only species present at window 1 , and it was abundant at windows 3 and 4 , but was very rare at window 2 ( 1 beetle) and was not found at the most anthropic windows (5 and 6). Canthon puncticollis was very abundant at window 3 , and was also found at a lower abundance at window 5. O. chevrolati retusus was the most abundant species at window 4 , but only 4 individuals of this species were caught at window 5 and none at any of the other windows. Phanaeus quadridens was caught at windows 3,5 and 6 , and was particularly abundant at the latter. Several beetles of this species were collected directly from the landscape, particularly along the livestock herding routes.

For complementarity among windows, the most dissimilar windows with respect to species composition are windows 1 vs. windows 5 and $6(100 \%$ complementarity index in both cases), with not a single species shared. The most similar windows are 3 and $5(50 \%)$ and windows 5 and $6(40 \%)$ with 3 species shared in both cases. The most similar in composition and abundance are windows 5 and 6 , which have the highest percentage of anthropic vegetation. The other windows share 1 or 2 species and their complementarity index ranges from 60 to $83.3 \%$.

The comparison of vegetation types revealed that abundance is highest in the forest where 666 beetles were caught, more than 4 times the number caught in the other 2 types of vegetation. The highest richness values were recorded for the forest and the anthropic vegetation $(n=$ $5)$. Although the low scrub had high richness (4 species), it had the lowest abundance of the 3 vegetation types with 57 beetles less than the anthropic vegetation (Table 3). Onthophagus mexicanus was only collected in the forest, while $O$. lecontei was found in all 3 vegetation types and was the most abundant species in the anthropic vegetation. Canthon humectus humectus was only found in anthropic vegetation, and $P$. quadridens was most abundant in anthropic vegetation and only 1 beetle was found in the low scrub. The most abundant species in the forest was $O$. chevrolati retusus, but it was not found in low scrub and its abundance was low in anthropic vegetation. Trox plicatus was not found in the anthropic vegetation.

On measuring the complementarity indexes for vegetation types, all vegetation types share 3 species. The low scrub has an index of $50 \%$ with the anthropic vegetation, and also with the forest. Complementarity was highest between the anthropic vegetation and the forest (57\%), owing to the difference in species abundance between the 2 types of vegetation.

The DCA (Fig. 3) (more than $70 \%$ of the variance was explained by axes 1 and 2) revealed differences in the species composition between the samples of each window and their associated species; this, as a function of the presence-absence of the different beetle species found in both the 6 windows and the 4 soil types.

The most separated windows are 1, 4 and 6 , with window 4 the most separated as it was the only window in which the abundance of $O$. mexicanus and $O$. lecontei was high. Window 6 was separated from the rest owing to the presence of $C$. humectus humectus (which was only collected at this window) and this window also had the highest abundance of $P$. quadridens. Only $T$. plicatus 
Table 3. Species abundance in different vegetation types for windows 1, 2, 3 and 4. (0: absent; +: rare (1-5 ind.); ++: not very abundant (6-20 ind.); +++: abundant (> 21 ind.); ++++: very abundant [ $>100$ ind. $])$.

\begin{tabular}{lccc}
\hline & $\begin{array}{c}\text { Anthropized } \\
\text { land (agricultu- } \\
\text { ral, livestock) }\end{array}$ & $\begin{array}{c}\text { Arboreal } \\
\text { vegetation }\end{array}$ & $\begin{array}{c}\text { Low } \\
\text { scrub }\end{array}$ \\
\hline C. (B.) puncticollis & 0 & ++ & +++ \\
C. humectus humectus & +++ & 0 & 0 \\
O. chevrolati retusus & + & ++++ & 0 \\
O. lecontei & +++ & ++++ & +++ \\
O. mexicanus & 0 & + & 0 \\
P. quadridens & ++ & 0 & + \\
T. plicatus & 0 & ++++ & +++ \\
\hline
\end{tabular}

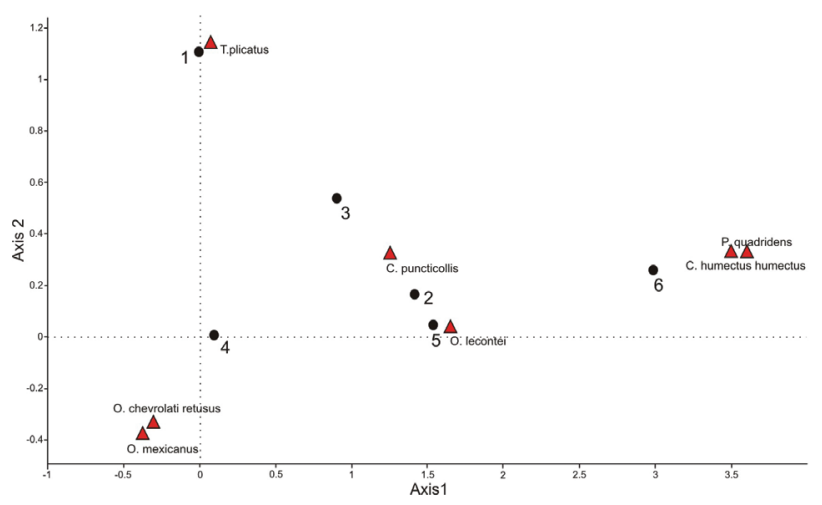

Figure 3. Detrended correspondence analysis showing the species associated with different sites and the corresponding type of soil. The first 2 axes of the DCA explain more than $70 \%$ of the variance. The filled circles indicate soil types and the crosses indicate the position of the species.

was found at window 1, which separates it from the rest of the windows. Phanaeus quadridens and C. humectus humectus were found at windows 5 and 6 where more food is available for the beetles given that these windows are on the livestock herding routes.

For soil types, the rocky soil is clearly separated from the others. On this type of soil we caught $T$. plicatus, which separates it from the other 3 types. On sandy soil, only $O$. lecontei and T. plicatus were caught. Loam and rocky loam soils have the highest species richness and abundance. This confirms that the presence of soils that allow beetles to nest is very important to the presence and abundance of these beetles (Fig. 3).

\section{Discussion}

Richness, abundance and microdistribution of copronecrophagous Scarabaeoidea. The fauna of this landscape is poor in both species and individuals, possibly the poorest of the southern Mexican Plateau. We feel that this results from a combination of circumstances: $a$ ), the nature of the soil; $b$ ), the limited rainfall; $c$ ), the very low availability of dung, and $d$ ), the distribution phenomena of the northeastern slope of the Trans-Mexican Volcanic Belt. a), the nature of the soil. The Scarabaeinae are nesting beetles and either the female or the pair prepares an underground nest. In the genus Phanaeus this is important because this species buries a mass of food at a certain depth and the female then transforms it into the brood ball (see Halffter and Edmonds, 1982). Similarly, Onthophagus beetles also bury food for their offspring (see Halffter and Edmonds, 1982), and Canthon makes a ball from the dung and rolls it, after which it buries the ball, although not very deeply.

For these beetles, it is important that the soil can be dug and tunnels can excavated in the soil. In the study region, the slopes and soil type as well as the high degree of rockiness and volcanic elements (including the badlands), do not favor nesting. This is further complicated since large piles of dung such as those produced by cattle, are scarce and only found in relatively small areas which are not necessarily the windows with the best soil quality. Based on this we would expect to find reproductive populations of Scarabaeinae where soils are loamy and relatively deep, while in the other places where they were found, they would be visitors that do not form stable populations.

On comparing the dominant soil types of each window with the richness and number of Scarabaeinae, we observe that the window with the lowest richness $(\mathrm{n}=1, T$. plicatus $)$ is the rockiest as it occurs in the badlands and the beetles cannot nest there. These soil characteristics do not affect the genus Trox, since it does not make deep nests. The females of this genus lay their eggs on the soil beneath animal carcasses which the larvae take advantage of and therefor, Trox is less affected by soil type (window 1).

At windows with more loamy soil (windows 3, 4, 5, and 6), richness is higher, since the soil allows different species to dig. The absence of C. humectus humectus and $P$. quadridens from windows 3 and 4 may result from low food availability since these are not pasturing areas. Window 5 is scrub with soil that is good for digging tunnels and this, together with an abundance of food makes this the window with the highest richness. Also, the largest species (C. humectus humectus and P. quadridens) were more abundant here than at the other windows.

Most Aphodiinae species do not nest, but rather reproduce in the dung and the soil immediately beneath it. Neither of the 2 Aphodiinae species was collected in traps, but rather under dung in areas surrounding the study area. Since they reproduce in dung, their presence is not much affected by soil type. 
b), limited rainfall. The MTZ does not have a Scarabaeinae fauna that is characteristic of arid regions, and this happens in almost all of North America, with the exception of the southern Peninsula of Baja California (Halffter et al., 2010). In the arid regions of northern Mexico (Sonora and Chihuahua up to the U.S.A.), there are few copronecrophagous species and the few that are found are also widely distributed in the dry pasture and scrub environments. One example is Canthon (Boreocanthon) puncticollis, which is found from the deserts of Baja California, Arizona and Chihuahua to the arid regions of the Mexican Plateau, the known southern limit of its distribution is Tehuacán, Puebla.

In the landscape we studied, the limited rainfall along with the other factors we discuss result in the absence of several beetle species that are typical of the southern Plateau.

c), limited availability of dung. The only medium-sized mammals that are relatively abundant are sheep and goats. Although cattle are present, they are much less abundant and there are no large tracts of land dedicated to cattle ranching, because the vegetation only allows goats and sheep to be pastured. Of the native animals, the only abundant mammals are rabbits and squirrels which produce very small amounts of dry scat. O. lecontei has been found associated with rabbit dung at windows on the southern Plateau (Arellano et al., 2009); however, we did not observe this in this study.

Food availability is very important, but in order for there to be greater species richness, in addition to food availability the soil must allow the beetles to nest, particularly for the larger species.

d), the distribution phenomena of the northeastern slope of the Trans-Mexican Volcanic Belt. In this region only 1 species that may have come down from the mountains was found: $O$. chevrolati retusus. This could be the result of not only differences in altitude, but also the combination of the 3 points mentioned above.

For other places where the Trans-Mexican Volcanic Belt comes into contact with a_more humid part of the Plateau and where cattle are present, Nearctic mountain elements have been found as marginal invaders (e.g. Copris armatus Harold and C. klugi Harold). In Mexico City, in Las Lomas de Chapultepec and in Contreras, Ceratotrupes fronticornis (Erichson) comes down into the city in some places where there are trees.

The absence of Dichotomius colonicus (Say) is noteworthy. This species has the Mexican Plateau distribution pattern, and is widely distributed including the southern portion of the Plateau. It is a large species that is mainly associated with cattle dung. Its absence from the study landscape appears to be associated with the near absence of large dung pats and the lack of deep soil since the nests of $D$. colonicus are extensive and deep.

It is also interesting to note that the 2 invasive species from the United States of America: Digitonthophagus gazella (Fabricius) and Euoniticellus intermedius (Reiche) were not found in the landscape studied. These species have expanded rapidly and widely in Mexico (Lobo, 1996; Lobo and Montes de Oca, 1997; Arellano and Halffter, 2003; Rivera and Wolff, 2007), even in desert areas. Reasons they might not inhabit the study landscape include the lack of appropriate dung (mainly cattle dung) and the high degree of rockiness of most of the soils.

All species are found throughout the study region, with the exception of $C$. puncticollis, which was only found at sites close to mountainsides. However, richness and particularly abundance vary locally. The microdistribution of the beetles in the region seems to point to a higher degree of aggregation in favorable sites. Microdistribution is not only aggregated, it is also highly nested. One exception to this is the aforementioned $C$. (B.) puncticollis, which is the only species typical of the arid sites within this landscape.

In summary, the most important characteristics for the presence of copronecrophagous beetles are soil type and food availability. Richness and abundance are greatest when both of these elements are favorable in the same place.

Biogeographic distribution patterns of the copronecrophagous Scarabaeoidea species present in the study area (Table 4). When the Plateau rose in the Miocene it became a very important area of diversification and speciation for ancient lineages of insects and plants. This is true for lineages of South American origin such as Canthon and Phanaeus, and for lineages of northern origin such as Onthophagus. The Plateau is thus one of the most important areas of in situ evolution and endemism in the MTZ.

In our study area we found the almost complete dominance (see Table 4) of species with the Plateau patterns, both those of the ancient lines with Neotropical affinities (Mexican Plateau distribution pattern), and those with northern affinities (Paleoamerican distribution pattern on the Plateau). The exceptions are also species of northern affinity, but partially associated with the mountains.

On comparing our results with those from the studies carried out in Metztitlán and Tehuacán, it is necessary to take into account that our study includes Scarabaeinae, Aphodiinae and Trogidae, while most authors only work with Scarabaeinae and Aphodiinae, or just the Scarabaeinae. For comparisons with other sites, the number of each taxonomic group sampled should be compared and not the overall numbers. Thus, here we only make comparisons between Scarabaeinae and Aphodiinae, leaving aside Trogidae at present. 
Fifty percent of the species collected $(n=8)$ are shared with Metztitlán (C. humectus humectus, C.(B.) puncticollis, O. lecontei, O. mexicanus and L. pseudolividus), and $37.5 \%$ are shared with Tehuacán (C.(B.) puncticollis, $O$. lecontei and L. pseudolividus). All 3 landscapes share only 3 species: C.(B.) puncticollis, O. lecontei and $L$. pseudolividus.

We collected a total of 960 beetles, while at Metztitlán and Tehuacán-Cuicatlán 58496 and 1599 were collected respectively. The high abundance at Metztitlán results mainly from Canthon humectus hidalgoensis (53 370 beetles). The favorable soil type and food availability make such a high abundance possible. Evidently, the aridity does not limit richness or abundance, given that all 3 are dry sites. It is more likely that the low beetle density in our study region is the result of the characteristics of the sites mentioned above.

The composition of the Scarabaeidae communities from the 3 arid regions of central Mexico is very different.
Although they share similarities in ecological conditions owing to the aridity and their relative geographic proximity, the biogeographic history is different. The fauna of the Barranca de Metztitlán is typical of the dry Plateau with affinities at the species level with the northeast of the Plateau, and even with the southern U.S.A. as occurs in our study area. In Tehuacán-Cuicatlán the fauna has Neotropical elements of modern expansion (geologically speaking) with few Plateau elements, and it has affinities with the upper Balsas Basin.

In tropical America almost all of the studies on the biodiversity and ecological distribution of dung beetles (and many other groups) have been carried out in regions or places where both the richness of species and that of individuals is very high. In general, these studies seek to document the effects of human activities, whether in terms of changes to the structure of natural communities, or due to forest fragmentation. Dung beetles are a good indicator group for illustrating the effects of anthropic activities

Table 4. Biogeographical affinities of the species captured in the study area and species found in other arid sites in central Mexico. Affinities are detailed in the Discussion. An asterisk indicates the species was found outside of the Metztitlán transect. NA (not applicable) indicates that trogid beetles were not sought in Metztitlán or Tehuacán

\begin{tabular}{lccc}
\hline Species & Biogeographical affinity & Metztitlán & Tehuacán \\
\hline Canthon (B) puncticollis & Mexican High Plateau & $\mathrm{x}\left({ }^{*}\right)$ & $\mathrm{x}$ \\
Canthon $(C)$ h. humectus & Mexican High Plateau & $\mathrm{x}$ & \\
Onthophagus chevrolati retusus & Paleoamerican Montane & $\mathrm{x}$ & $\mathrm{x}$ \\
Onthophagus lecontei & Paleoamerican - High Plateau & $\mathrm{x}\left({ }^{*}\right)$ & \\
Onthophagus mexicanus & Paleoamerican - High Plateau & $\mathrm{NA}$ & $\mathrm{NA}$ \\
Trox plicatus & Mexican High Plateau & & \\
Phanaeus quadridens & Paleoamerican & $\mathrm{x}$ & $\mathrm{x}$ \\
Labarrus pseudolividus & Nearctic & & \\
Pseudagolius coloradensis & & \\
\hline
\end{tabular}

(Halffter and Favila, 1983) and this has brought about the repetition of similar approaches in different regions or ecological conditions (Nichols et al., 2007).

We chose a region where preliminary collection indicated the existence of a poor faunal group due to the extreme conditions mentioned in this paper. We feel that the results obtained from this study highlight the usefulness of studying the formation and structure of assemblages of different groups under ecological conditions that are unfavorable.

\section{Acknowledgments}

The authors thank FOMIX-CONACYT, Gobierno del Estado de Veracruz 34103, "Agroecosistemas y conservación de la biodiversidad en el centro de Veracruz" project for funding the field work of this study. We are grateful to Mario Zunino (Urbino University) for identifying the species of Onthophagus, and to Francisco Cabrero (Universidad Complutense of Madrid) for identifying the Aphodiini collected during this study.

\section{Literature cited}

Arellano, L. and G. Halffter. 2003. Gamma diversity: Derived from and a determinant of alpha diversity and beta diversity, an analysis of three tropical landscapes. Acta Zoológica Mexicana. 90:27-76.

Arellano, L., A.J. Martínez, E. Lezama-Delgado and M. Zunino. 2009. Dung beetles (Coleoptera:Scarabaeinae) in rabbit 
dung heaps: First report for Mesoamerica. The Coleopterists Bulletin. 63:101-104.

Arroyo-Rodríguez, V., E. Pineda and F. Escobar. 2009. Value of small patches in the conservation of plant-species diversity in highly fragmented rainforest. Conservation Biology 23:729739.

Cabrero-Sañudo, F. J., M. Dellacasa, I. Martínez, J. M. Lobo and G. Dellacasa. 2010. Distribución de las especies de Aphodiinae (Coleoptera, Scarabaeoidea: Aphodiidae) en México. Acta Zoológica Mexicana (n.s.) 26:323-399

Colwell, R. K. 2005. EstimateS: statistical estimation of species richness and shared species from samples. Department of Ecology and Evolutionary Biology, University of Connecticut, USA.

Colwell, R. and J. A. Coddington. 1994. Estimating terrestrial biodiversity through extrapolation. Philosophical Transactions of the Royal Society of London, Series B-Biological Sciences. 345:101-118.

Conabio (Comisión Nacional para el Conocimiento y Uso de la Biodiversidad). Collections: http://conabioweb.conabio.gob. mx; last access: 24-03-2011.

Cházaro, M. 1992. Exploraciones botánicas en Veracruz y estados circunvecinos. La Ciencia y El Hombre 10:65-115.

Dellacasa, M., R. D. Gordon and G. Dellacasa. 2002. Aphodiinae described or recorded by Bates in Biologia Centrali-Americana (Coleoptera, Scarabaeoidea: Aphodiidae). Acta Zoológica Mexicana. (n.s.) 86:155-223.

Gauch, H. G., Jr. 1982. Multivariate analysis in community ecology. Cambridge University Press, Cambridge. 298 p.

Halffter, G. 1962. Explicación preliminar de la distribución geográfica de los Scarabaeidae mexicanos. Acta Zoológica Mexicana 5:1-17.

Halffter, G. 1964. La Entomofauna Americana, ideas acerca de su origen y distribución. Folia Entomológica Mexicana 6:1-108.

Halffter, G. 1976. Distribución de los insectos en la Zona de Transición Mexicana. Relaciones con la entomofauna de Norteamérica. Folia Entomológica Mexicana 35:1-64.

Halffter, G. 1987. Biogeography of the montane entomofauna of Mexico and Central America. Annual Review in Entomology 32:95-114.

Halffter, G. and W. D. Edmonds. 1982. The nesting behavior of Dung Beetles (Scarabaeinae). An ecological and evolutive approach. Instituto de Ecología. México, D. F. 10:176 p.

Halffter, G. and M. E. Favila.1993. The Scarabaeinae (Insecta: Coleoptera) an animal group for analyzing, inventorying and monitoring biodiversity in tropical rainforest and modified landscapes. Biology International 27:15-21.

Halffter, V. and G. Halffter. 2003. Nuevas subespecies de Canthon humectus (Say) (Coleoptera: Scarabaeidae: Scarabaeinae). Folia Entomológica Mexicana 42:329-340.

Halffter, G. and A. Martínez. 1977. Monografía de los Canthonina americanos, IV. (Coleoptera, Scarabaeidae). Folia
Entomológica Mexicana 38:29-107.

Halffter, G., J. R. Verdú, J. Márquez and C. E. Moreno. 2008. Biogeographical analysis of Scarabaeinae and Geotrupinae along a transect in Central Mexico. Fragmenta entomologica 40:273-322.

Halffter, G., J. R. Verdú, C. E. Moreno and V. Halffter. 2012. Historical and ecological determinants of dung beetle assemblages in two arid zones of central Mexico. Journal of Arid Environments 76:54-60.

Hammer, O., D. A. T. Harper and P. D. Ryan. 2009 Past: Paleontological Statistics, Version 1.78. http://folk.uio.no/ ohammer/past; last access: 24-02-2011.

Hill, M. O. and H. G. Gauch. 1980. Detrended Correspondence Analysis: an improved ordination technique. Plant Ecology 42:47-58.

Legendre, L. 2000. Numerical ecology. Elsevier Publishers. Amsterdam. 853 p.

Lindenmayer, D. B., S. McIntyre and J. Fisher. 2003. Birds in eucalypt and pine forests: landscape alteration and its implications for research models of faunal habitat use. Biological Conservation 110:45-53.

Llorente-Bousquets, J. 1996. Biogeografía de artrópodos de México: ¿Hacia un nuevo enfoque? In Biodiversidad, taxonomía y biogeografía de artrópodos de México, J. Llorente-Bousquets, A. N. García and E. González (eds.). UNAM. México, D. F. p. 41-56.

Lobo, J. M. 1996. Diversity, biogeographical considerations and spatial structure of a recently invaded dung bettle (Coleoptera:Scarabaeoidea) community in the Chihuahuan Desert. Global Ecology and Biogeography Letters 5:342-352.

Lobo, J. M. and E. Montes de Oca. 1997. Spatial microdistribution of two introduced dung beetles species Digitonthophagus gazella (F.) and Euoniticellus intermedius (Reiche) (Coleoptera: Scarabaeidae) in an arid region of northern Mexico (Durango, Mexico). Acta Zoológica Mexicana 71:17-32.

Magurran, A. E. 2004. Measuring biological diversity. Blackwell Publishing, Oxford. 256 p.

Marshall, C. J. and J. K. Liebherr. 2000. Cladistic biogeography of the Mexican Transition Zone. Journal of Biogeography 27:203-216

Miranda, F. and E. Hernández. 1963. Los tipos de vegetación de México y su clasificación. Boletín de la Sociedad Botánica de México 28:29-179.

Moreno, C. E. and G. Halffter. 2000. Assessing the completeness of bat biodiversity inventories using species accumulation curves. Journal of Applied Ecology 37:149-158.

Morón, M. A. and R. Terrón. 1984. Distribución altitudinal y estacional de los insectos necrófitos en la Sierra Norte de Hidalgo, México. Acta Zoológica Mexicana (n.s.) 3:147.

Morrone, J. J. and J. Márquez. 2001. Halffter's Mexican Transition Zone, beetle generalized tracks and geographical homology. Journal of Biogeography 28:635-650. 
Nichols, E., T. Larsen, S. Spector, A. Davis, F. Escobar, M. Favila and K. Vulinec. 2007. Global dung beetle response to tropical forest modification and fragmentation: a quantitaive review and meta-analysis. Biological Conservation 137:1-19.

Numa, C., J. R. Verdú and A. Sánchez. 2009. Effect of landscape structure on the spatial distribution of Mediterranean dung beetle diversity. Diversity and Distributions 15:489-501.

Portilla, O. E. 1980. Suelos en la región Xalapa y su relación con la productividad. B. Sc. Thesis, Universidad Veracruzana, Veracruz, Mexico. $39 \mathrm{p}$.

Reyes-Castillo, P. 2003. Las ideas biogeográficas de Gonzalo Halffter: importancia e impacto. In Una Perspectiva Latinoamericana de la Biogeografía, J. J. Morrone and J. Llorente-Bousquets (eds.). Las Prensas de Ciencias. México, D. F. p. 99-108.

Rivera, C. and M. Wolff. 2007. Digitonthophagus gazella (Coleoptera: Scarabaeidae): distribution in America and two new records for Colombia. Revista Colombiana de Entomología 33:190-192.

Rzedowski, J. 1972. Relaciones geográficas y posibles orígenes de la flora de México. Boletín de la Sociedad Botánica de México 29:131-177.

Rzedowski, J. 1973. Geographical relationships of the flora of Mexican dry regions. In Vegetation and vegetational history in northern Latin America, A. Graham (ed.). Elsevier Scientific Company. Amsterdam. p. 61-72.

Rzedowski, J. 1978. Vegetación de México. Ed. Limusa, México,
D. F. 432 p.

Rzedowsky, J. 1991. Diversidad y orígenes de la flora fanerogámica de México. Acta Botánica Mexicana 14:3-21.

Sclater, P. L. 1858. On the general geographical distribution of the members of the class Aves. Journal of the Proceedings of the Linnean Society of London. Zoology 2:130-136.

Vaurie, P. 1955. A revision of the genus Trox in North America (Coleoptera: Scarabaeidae). Bulletin American Museum of Natural History 106:1-90.

Verdú, J., C. Moreno, G. Sánchez-Rojas, C. Numa, E. Galante and G. Halffter. 2007. Grazing promotes dung beetle diversity in the xeric landscape of a Mexican Biosphere Reserve. Biological Conservation 140:308-317.

Waide, R. B., M. R. Willig, C. F. Steiner, G. Mittelbach, L. Gough, S. I. Dodson, G. P. Juday and R. Parmenter. 1999. The relationship between productivity and species richness. Annual Review of Ecology and Systematics 30:257-300.

Wallace, A. R. 1876. The geographical distribution of animals. Macmillan and Company, London. 503 p.

Zunino, M. and G. Halffter. 1988. Análisis taxonómico, ecológico y biogeográfico de un grupo americano de Onthophagus (Coleoptera: Scarabaeidae). Monografías IX, Museo Regionale di Scienze Naturali, Torino. Italia. 211 p. + graphs and maps.

Zunino, M. and A. Zullini. 1995. Biogeografía: la dimensione spaziale dell evoluzione. Case Editrice Ambrosiana, Milano. $373 \mathrm{p}$. 